\title{
PROFESIONALNA (SLOVENSKA) VOJSKA?
}

\section{PROFESSIONAL (SLOVENIAN) ARMED FORCES?}

Professional article

Povzetek Slovenska vojska se je hkrati s prehodom na popolnjevanje s poklicnimi pripadniki odločila za profesionalizacijo. Toda poklicna in profesionalna vojska nista sopomenki. Vojaška profesija ima svoje značilnosti, ki izhajajo iz splošnega pojma profesije. Za profesijo so značilni strokovnost, trajno izobraževanje, profesionalna avtonomija in avtoriteta, profesionalna etika in druge značilnosti. Od tega, koliko in kako so te značilnosti izražene v Slovenski vojski, je odvisno, ali je že danes mogoče govoriti o profesionalni vojski ali pa je to za zdaj še dolgoročni cilj, za katerega si prizadeva.

Ključne Slovenska vojska, vojaška profesija, profesionalna vojska.

besede

Abstract Along with the decision for an all-volunteer force the Slovenian Armed Forces are also promoting military professionalism. Military profession is characterized by certain elements that distinguish it as such. Expert knowledge, continuous education, professional autonomy and authority, professional ethics are some of these characteristics. Whether at all and to what degree these characteristics are present in the Slovenian Armed Forces today is an indicator to whether professionalism is already a characteristics of the force or still a long-term objective.

\section{Key words Slovenian Armed Forces, military profession, military professionalism.}

Uvod Slovenska vojska (SV)se ob 20-letnici svojega obstoja kot vojska samostojne države predstavlja kot profesionalna vojska. Ob tem je vsebina te profesionalnosti pogosto nejasna in se neredko preprosto enači z dejstvom, da je po načinu popolnjevanja pretežno poklicna vojska. Toda ali je za profesionalnost vojske resnično ključno popolnjevanje s poklicnimi pripadniki ali pa je način popolnjevanja nepomemben in 
je profesionalnost odvisna od drugih dejavnikov? Na katere značilnosti vojske in vojaškega poklica se torej ocena o profesionalnosti sploh nanaša? In koliko so te značilnosti izražene v SV?

Razmišljanje $\mathrm{v}$ tej razpravi se razvija ob sestavinah splošnega pojma vojaške profesije, z namenom, prikazati ustrezanje posameznih značilnosti slovenske vojaške profesije splošnemu pojmu vojaške profesije ter s tem upravičenost poimenovanja sedanje slovenske vojaške prakse z nazivom profesija. V razpravi so za osvetlitev tega vprašanja najprej iz priznanih definicij pojma vojaške profesije povzete značilnosti vojaške profesije in kumulativno izpostavljene kot bistvena določila splošnega pojma vojaške profesije. S tem je pridobljena zgornja premisa, potrebna za sodbo. Posamične dejanske značilnosti slovenske vojaške profesije so pridobljene z opazovanjem $\mathrm{z}$ metodo lastne udeležbe ${ }^{1}$ ter nato $\mathrm{z}$ metodo indukcije, generalizirane na raven celotne slovenske vojaške prakse. Tako je pridobljena spodnja premisa in $\mathrm{s}$ tem omogočena subsumpcija ter sodba o skladnosti posamičnega dejanskega stanja s splošnim pojmom, torej sodba o tem, ali slovenska vojaška profesija vsebuje značilnosti, ki so bistvene za vojaško profesijo, ali pa je o njej kot o profesiji mogoče govoriti le pogojno. Ker je metoda indukcije, ki lastna doživljanja in opažanja generalizira na celoto, inherentno subjektivna, je sodba o naravi slovenske vojaške profesije odvisna od vsakega opazovalca. Ta razprava je tako eden izmed mogočih pogledov na stanje slovenske vojaške profesije, merjene ob splošnem pojmu vojaške profesije.

\section{ZNAČILNOSTI VOJAŠKE PROFESIJE}

Za oceno o profesionalnosti vojske je treba najprej dobiti temeljni vpogled v pojem profesije. Kot vsak pojem je tudi pojem profesije definiran na veliko načinov, katerih prepletanje da neki bolj ali manj zanesljiv vpogled v temeljne značilnosti profesije. V nadaljevanju sta povzeta dva pogleda na temeljne značilnosti vojaške profesije.

Sarkesian in Connor izpostavljata naslednje elemente vojaške profesije:

- jasno določeno področje kompetence, ki temelji na strokovnem znanju;

- sistem neprekinjenega izobraževanja, ki zagotavlja vzdrževanje strokovne kompetence;

- dolžnost do skupnosti, ki ji služi, brez skrbi za povračilo;

- sistem vrednot, ki oblikuje profesionalni značaj in odnos do skupnosti;

- deluje znotraj institucionalnega okvira;

- ima nadzor nad svojim sistemom nagrajevanja in kaznovanja in je v položaju, da določa kakovost vhodnega kadra (Sarkesian in Connor, 2006, str. 27).

Abrahamsson navaja, da člani profesije:

- posedujejo visoko stopnjo specializiranega, teoretičnega znanja ter določene metode in načrte za uporabo tega znanja v vsakodnevni praksi;

\footnotetext{
Avtorica je opravljala različne vojaške dolžnosti v enotah in poveljstvih Slovenske vojske: načelnica operative $v$ bataljonu, namestnica poveljnika bataljona, načelnica štaba brigade in pribočnica načelnika Generalštaba Slovenske vojske.
} 
- opravljajo svoje naloge po nekakšnih etičnih pravilih, kodeksu;

- spadajo skupaj oziroma jih povezuje visoka stopnja korporativnosti (Abrahamsson v Jelušič, 1997, str. 106).

Jelušič navaja naslednje značilnosti vojaške profesije:

- strokovnost, ki obsega specialistično znanje in pripadajoče veščine, ki so posledica dolgotrajnega izobraževanja in izkušenj;

- profesionalna avtonomija;

- odgovornost;

- služenje uporabniku, ki je v primeru vojske družba ali država;

- koncept neomejene službe;

- korporativnost;

- neomejena služba;

- profesionalna kultura;

- sankcioniranje znotraj profesije;

- profesionalna avtoriteta (Jelušič, 1997, str. 109).

Ker so značilnosti profesije (kot profesije) za vse profesije enake, se med seboj razlikujejo prvenstveno po področju svoje kompetence. Za področje kompetence vojaške profesije je tako značilno »upravljanje nasilja« (Harold Lasswell v Jelušič, 1997, str. 109). Upravljanje nasilja, ki ga izvajajo oborožene sile, od vojaških profesionalcev zahteva, da organizirajo, opremljajo in urijo sile, načrtujejo njihove aktivnosti in usmerjajo njihovo delovanje (Huntington v Jelušič, 1997, str. 109).

Iz predstavljenih pogledov na značilnosti profesije, in še posebej vojaške profesije, je mogoče nanizati značilnosti vojaške profesije, kot jih izpostavljajo navedeni avtorji:

- visoka stopnja specializiranega teoretičnega znanja s področja upravljanja nasilja in metode za uporabo tega znanja v praksi;

- za pridobitev in ohranjanje zahtevane ravni vojaške strokovne usposobljenosti ustrezen sistem izobraževanja in usposabljanja, katerega standarde določa vojaška profesija sama;

- profesionalna avtonomija;

- profesionalna avtoriteta;

- lastni standardi profesionalnega vedenja oziroma profesionalne etike, ki skupaj z drugimi značilnostmi oblikujejo specifično profesionalno kulturo;

- nadzor nad sistemom nagrajevanja in kaznovanja članov profesije ter nadzor nad kakovostjo vhodnega kadra;

- namen izvajanja profesije je služenje skupnosti in ne lastnim interesom. Ob morebitnem navzkrižju interesov ima interes skupnosti prednost pred interesom posameznega člana profesije ali njegovih profesionalnih kolegov. Z namenom profesije je povezana tudi odgovornost njenih članov do skupnosti;

- neomejena služba;

- korporativnost;

- delovanje znotraj institucionalnega okvira. 
Tako nanizane značilnosti vojaške profesije torej ločujejo vojaško profesijo od vseh drugih človekovih dejavnosti. Medtem ko nekatere teh značilnosti delujejo samoumevno, pa se za druge zdi, da se ne skladajo povsem z naravo vojaške organiziranosti in delovanja. O zadnjih bo več govora v tretjem poglavju.

Najprej je treba dodatno pojasniti prvo značilnost, to je strokovno znanje. Značilnost profesije, tudi vojaške, sta visoko razvito, specializirano teoretično znanje in usposobljenost, da se to znanje uporabi v praksi. Profesija je torej usmerjena k praktični uporabi teoretičnega znanja, torej k veščini te uporabe, pri čemer v okviru profesije veščina temelji na obsežnem in visokospecializiranem korpusu teoretičnega znanja in metod njegove uporabe. Profesija ima podlago v pojmovanju, v pojmovnem sistemu, ki se neprestano razvija na podlagi praktičnih izkušenj, raziskovanja in znanstvenih spoznanj. V tem se profesija razlikuje od obrti, ki ni zgolj veščinsko orientirana, temveč tudi veščinsko utemeljena. V vojaški profesiji je, glede na zahtevo po specializiranem teoretičnem znanju kot posledici dolgotrajnega izobraževanja in izkušenj, treba najprej pogledati, katera kategorija pripadnikov vojske izpolnjuje tako merilo. Gotovo je, da poklicni vojaki ne spadajo v kategorijo tistih, ki posedujejo visoko stopnjo specializiranega, teoretičnega znanja. Njihovo temeljno usposabljanje traja tri mesece in je povsem veščinsko naravnano, temu po potrebi sledi še povprečno do tri mesece osnovnega vojaškega usposabljanja za opravljanje dolžnosti, ki zahtevajo specifično veščinsko znanje. Tako naravnano usposabljanje gotovo ni podlaga za pridobitev za profesijo bistvenega teoretičnega znanja. Če katera kategorija, potem so častniki tisti, ki glede na zahtevano izhodiščno visoko strokovno izobrazbo in poznejše dalj časa trajajoče tudi ali predvsem teoretično usmerjeno častniško šolanje, izpolnjujejo to merilo. Vprašanje, ki se lahko postavi v zvezi z omejitvijo nosilcev vojaške profesije, je, ali podčastniki spadajo med vojaške profesionalce ali pa sta njihovo šolanje in narava dela utemeljena predvsem na veščini. Vsaj kar se tiče nižjih podčastnikov, je odgovor razmeroma preprost. Glede na izhodiščno zahtevano izobrazbo, ki je enaka tisti, zahtevani za poklicne vojake in veščinsko naravnanost osnovnega vojaškega izobraževanja podčastnikov, nižji podčastniki ne posedujejo visoke stopnje specializiranega teoretičnega znanja in jih ni mogoče prišteti med nosilce vojaške profesije. Vprašanje pa je, ali zahteva po visoki izobrazbi ter z delom pridobljene izkušnje višjih in visokih podčastnikov utemeljujejo ugotovitev, da so ti nosilci za profesijo zahtevane visoke stopnje specializiranega, teoretičnega znanja ter določenih metod in načrtov za uporabo tega znanja v vsakodnevni praksi. Če je to tako, potem razlikovanje med častniki in višjimi podčastniki nima podlage. Tudi zato odgovor na to vprašanje ni enostaven, poglobljena razprava o tem pa bi presegla namen tega prispevka. Zato naj za nadaljevanje razmišljanja v tem prispevku zadostuje izhodišče, da za uspešno opravljanje svojega dela nedvoumno samo častniki potrebujejo specializirano, na teoretičnem znanju temelječe, dolgotrajnejše izobraževanje. To razlikovanje v okviru razmišljanja o vojaški profesiji pomeni, da pravzaprav govorimo o profesionalnosti častniškega zbora (Jelušič, 1997, 106) in ne vseh pripadnikov vojske. Tako se vprašanje o profesionalnosti vojske zoži na vprašanje o profesionalnosti častniškega zbora. Navedene značilnosti vojaške profesije naj bi torej kazal častniški zbor, če je profesionalen. 


\section{ZNAČILNOSTI VOJAŠKE PROFESIJE V SLOVENSKI VOJSKI}

Slovenska vojska želi postati profesionalna vojska. Profesionalizacijo dojema kot dolgoročni cilj. Resolucija o splošnem dolgoročnem programu razvoja in opremljanja Slovenske vojske do leta 2025 (ReDPROSV25, 2010) določa profesionalizacijo kot enega izmed treh dolgoročnih ciljev SV in pravi: »S pospešenim procesom funkcionalne profesionalizacije transformirati Slovensko vojsko v visoko profesionalno in učinkovito vojaško organizacijo, sposobno skupnega delovanja tudi $\mathrm{v}$ večnacionalnem vojaškem okviru, skladno s sodobnimi koncepti in doktrinami, ter v razumnem obsegu ohranjati njeno sposobnost za učinkovito izvajanje nalog, izhajajočih iz doktrine oblikovanja in delovanja vojaške strateške rezerve.« Znotraj doseganja tega cilja ReDPROSV25 določa naslednje prednostne naloge razvoja:

- vzpostavitev učinkovitejšega sistema upravljanja kadrovskih virov;

- izoblikovanje celovitega sistema vojaškega izobraževanja in usposabljanja v sodelovanju z javnim izobraževalnim sistemom;

- poznavanje, razvoj in uporaba sodobnih doktrin, povečanje sposobnosti skupnega delovanja;

- učinkovita strategija komuniciranja z javnostmi in sodelovanja s civilno-družbenimi organizacijami;

- dvig organizacijske in varnostne kulture v Slovenski vojski ter uveljavljanje vojaške etike.

Tako postavljen dolgoročni cilj kaže, da se SV na ravni strateških dokumentov zaveda, da zgolj s prehodom na poklicno vojsko profesionalizacija ni opravljena. $\mathrm{Z}$ določitvijo prednostnih nalog se resolucija dotika nekaterih značilnosti vojaške profesije, nanizanih v predhodnem poglavju. To lahko pomeni dvoje: ali je proces profesionalizacije na teh področjih najpomembnejši ali pa je iz trenutnega stanja profesionalizacije v SV razvidno, da je na teh področjih najbolj problematičen. Za odgovor na to vprašanje je treba pogledati, kako se posamezne značilnosti vojaške profesije izražajo v SV danes. V ta namen bomo na kratko preleteli nekatere značilnosti vojaške profesije in si tako ustvarili vtis o stanju profesionalizacije v SV.

\subsection{Strokovno znanje v Slovenski vojski}

Prva in osrednja značilnost profesije sta visoko specializirano znanje in njegova praktična uporaba. Slovenska vojaška profesija znanje skoraj v celoti črpa iz tujih virov, in sicer pretežno iz virov nekdanje JLA in ameriških oboroženih sil². Ker je strokovno znanje načeloma univerzalno, to ni problematično, čeprav je vojaška stroka $\mathrm{v}$ tem pogledu nekoliko specifična, saj se je predvsem v času blokovske delitve razvijala dvotirno. Ne glede na to so temeljna spoznanja tudi na področju vojaške stroke generalna vsaj v evropski tradiciji. Dejstvo, da vojaška profesija črpa svoje znanje skoraj v celoti iz tujih virov, tako ni problematično. Pomembno pa je, da mora biti znanje pojmovno in sistematizirano, tako da oblikuje neki skupen

\footnotetext{
Minister za obrambo je s seznamom vojaško-strokovne literature, ki ni bila izdana v okviru Ministrstva za obrambo in lahko služi kot dopolnilna literatura za izobraževanje in usposabljanje, odobril uporabo neslovenskih virov za potrebe izobraževanja in usposabljanja (MO RS, št. 604-16/2006-2, 2006).
} 
teoretični okvir kot podlago za prakso. Na tej točki je v znanju slovenske vojaške profesije vrzel. Slovenska vojaška profesija je v enem delu razmeroma ažurna pri prevzemanju tujih konceptov in metod, vendar se ustvarja vtis, da teh konceptov in metod ne pojmuje in ne sistematizira, temveč jih zgolj mehanično prevzema in uporablja, pa še to velikokrat s pridržkom. Kar nekaj je primerov, ko je iz dejanske uporabe posameznih prevzetih konceptov in metod razvidno, da so ti na neki način zgolj presajeni v slovensko vojaško okolje, ne da bi jih to okolje ustrezno razumelo, sprejelo in umestilo. Nedorečenost in dvoumnost, samovoljne interpretacije, neustreznost normativnih podlag, odsotnost ali prilagajanje standardov in meril, pomanjkanje vsebinske podlage in metodike ali pa preprosta ignoranca vsebine in pomena različnih strokovnih kategorij ${ }^{3}$ kažejo na pomanjkljivo razumevanje nekaterih temeljnih konceptov vojaške stroke. S stališča ocene o profesionalnosti ni pomembno, kakšen je vzrok za neustrezno uporabo posameznega koncepta in s tem za vprašljivo stanje stroke v SV. Lahko gre za nerazumevanje namena ali upravičevanje vloženih virov, neustrezno načrtovanje, neusklajenost normativnih podlag, pomanjkanje praktičnih izkušenj, prikrojeno prikazovanje doseženega, odsotnost vsebinskih podlag ali nesposobnost strokovne debate ob uveljavljanju standardov. Ni pomembno, ali temeljnih konceptov nosilci vojaške profesije preprosto ne razumejo, ne dojamejo njihovega pomena ali pa jih namenoma uporabljajo pomanjkljivo, prirejeno ali napačno. Za oceno profesionalnosti je pomembno zgolj to, da je iz načina uporabe teh temeljnih konceptov in metod razvidno, da slovenska vojaška stroka ne obvlada vseh osnov vojaškega strokovnega znanja in njegove uporabe.

Ob trenutnem stanju se ustvarja vtis, da je slovenska vojaška stroka v želji po (pre) hitrem dohajanju razvitih velikih vojsk prevzemala tuje koncepte in rešitve, obenem pa ni bila sposobna hitre strokovne rasti utrditi, razširiti na celotno vojaško profesijo ter novega znanja in konceptualnih rešitev ustrezno pojmovati in sistematizirati, torej prevesti v doktrino, tako formalno kot dejansko zavezujočo za vse vojaške strokovnjake. Iz obstoječih doktrinarnih dokumentov ni mogoče razbrati, da bi bila produkcija doktrine v SV prilagojena in bi izhajala iz nalog, strukture, značilnosti in potreb SV. Struktura vojaške strokovne literature v SV je sicer formalno določena ${ }^{4}$, vendar gre v veliki meri za prevzeto strukturo doktrine Nata. Tako struktura doktrine SV neposredno temelji na posameznih doktrinarnih dokumentih Nata, ne da bi bila prilagojena potrebam in predvsem zmožnostim SV, ob tem pa je glede na razpoložljive

\footnotetext{
3 Med te kategorije spadajo operativne zmogljivosti, operativni cikel, mobilizacija, pripravljenost za delovanje, ugotavljanje pripravljenosti, načrtovanje usposabljanja po metodi seznama bistvenih nalog, proces načrtovanja delovanja, poveljevanje na podlagi poslanstva, oblikovanje poveljniških mest, razmerja poveljevanja in kontrole ipd. Primeri nerazumevanja pomena različnih pojmov so na primer: načrtovanje operativnih zmogljivosti na podlagi neustreznih formacij in s prilagajanjem zahtev materialne popolnitve sedanjemu stanju, ne da bi se hkrati ustrezno prilagodila raven pričakovane zmogljivosti; ocenjevanje pripravljenosti enot s strani pripadnikov SV, ki nimajo nikakršnih izkušenj na ocenjevanih področjih in se zato posamezni elementi ne ocenjujejo vsebinsko, temveč se zapisuje zgolj formalno izpolnjevanje predpisanih meril; načrtovanje usposabljanja na podlagi seznama bistvenih nalog v razmerah, ko metoda za zdaj nima podlage v vsebini, torej $v$ strukturi bistvenih nalog, na podlagi katere bi bilo mogoče iz vrst delovanja, vsebovanih v poslanstvu posamezne enote, izpeljati bojne naloge, postopke, drile in individualne veščine, ki jih morajo podenote in posamezniki obvladati, da bi bila enota sposobna opravljati naloge iz poslanstva.

4 Struktura vojaške strokovne literature je določena z ukazom GŠSV za uveljavitev hierarhije vojaške strokovne literature (GŠSV, št. 604-7/2006-40, 2007).
} 
človeške vire v SV zelo ambiciozno zamišljena. Preveliki ambicioznosti ustreza tudi (ne)realizacija produkcije doktrine glede na zamišljeno strukturo ${ }^{5}$. Za zagotavljanje doktrinarne interoperabilnosti v okviru Nata sicer idealno zamišljena struktura slovenske vojaške doktrine glede na velike razlike v ciljnih zmogljivostih in razpoložljivih človeških virih ne ponuja ustreznega okvira za sistematizacijo potrebnega slovenskega vojaškostrokovnega znanja. Glede na omejene vire bo treba omejiti tudi želje in zahteve po produkciji in sistematizaciji lastnega znanja, saj vojaški profesionalni zbor s 1200 člani ne more producirati, sistematizirati in obvladovati enakega obsega znanja kot sistemi s 100.000 in več člani. Struktura doktrine pa se mora samoomejevanju nujno prilagoditi.

Za stanje na področju strokovnega znanja je značilna tudi uporaba strokovne terminologije kot podlage medsebojne komunikacije med vojaškimi strokovnjaki. Del vojaških strokovnjakov uporablja najsodobnejšo vojaško strokovno terminologijo, prevzeto večinoma s šolanj v tujini, iz tuje strokovne literature ter s skupnega usposabljanja in delovanja s tujimi vojskami, drugi del vojaških strokovnjakov pa sodobne terminologije sploh ne pozna, ne uporablja in tudi ne razume. V posameznih primerih se kljub definirani strokovni terminologiji namenoma uporabljajo termini, ki nimajo podlage $\mathrm{v}$ doktrini ${ }^{6}$. Ob tem je zanimivo, da je strokovna terminologija sicer eno izmed formalno bolje urejenih področij slovenske vojaške stroke ${ }^{7}$, le da strokovne literature veliko vojaških strokovnjakov ne pozna, ne uporablja ali jo ignorira. V prepričanju, da za tujo strokovno terminologijo ne obstajajo ustrezni prevodi, velik del uporablja kar angleško terminologijo. Podoben pojav ni prisoten samo v zvezi s strokovno terminologijo, temveč je tudi sicer prisotna uporaba tuje strokovne literature, tudi v primerih, ko ustrezna slovenska vojaška strokovna literatura obstaja. To je mogoče pripisati več vzrokom: (1) dolgotrajni odsotnosti lastne literature, zaradi česar so se vojaški profesionalci navadili na uporabo nabora tuje terminologije in literature; (2) nepoznavanju lastnih virov, predvsem pri tistih, ki so se izobraževali v tujih šolah in tam uporabljali tujo literaturo; (3) neustreznosti lastnih doktrinarnih dokumentov ali strokovne literature, ki je prevečkrat zgolj prevod enega ali več tujih dokumentov, ni prilagojena posebnostim in potrebam SV ali pa je celo strokovno vprašljiva ${ }^{8}$. Vse opisano prispeva $\mathrm{k}$ vedno večji razdrobljenosti in naključnosti strokovnega znanja in razvoja.

\footnotetext{
${ }_{5}$ Na prvi ravni vojaške strokovne literature sta od predvidenih 11 do zdaj izdana 2 dokumenta, na drugi ravni pa od predvidenih približno 60 največ 3.

${ }_{6}$ Tako na primer pojem mednarodne operacije in misije (MOM), ki ni vojaški doktrinarni pojem, brez vojaške strokovne utemeljitve izpodriva že uveljavljeni in doktrinarni pojem operacije kriznega odzivanja (OKO), ki je določen z Vojaško doktrino (2006) in usklajen s strokovno terminologijo zavezniških vojsk.

Glej Angleško-slovenski terminološki slovar (Darija Brinc, Tamara Derman Zadravec, Branimir Furlan in Tadeja Hafner, 2006), Začasni angleško-slovenski vojaški priročni slovar (Branimir Furlan in Marjan Mahnič, 1996) in Slovensko-angleški vojaški priročni slovar (Branimir Furlan in Marjan Mahnič, 1999).

\& Primer zadnjega je uvedba osnutka Navodila za štabno delo v poskusno uporabo na ravni celotne SV leta 2007(GŠSV, št. 603-36/2007-1, 2007), ki je iz uporabe izrinilo že široko sprejeta in uveljavljena Pravila štabnega dela ter na taktično raven načrtovanja delovanja uvedlo povsem neustrezno mešanico operativnega planiranja in procesa načrtovanja delovanja taktične ravni. Zaradi neuporabnosti predpisanega procesa načrtovanja za taktično raven so se predvsem $v$ enotah, ki morajo izdelovati uporabne načrte in na podlagi njih tudi dejansko delovati, zatekli k uporabi pretežno ameriške strokovne literature za načrtovanje delovanja.
} 
Mogoče je treba enega izmed izvorov zgoraj opisanih pojavov iskati v vedno bolj abstraktnem mišljenju pri prakticiranju vojaške profesije. Abstrahiranje kot miselni postopek je uporabno v okviru induktivne metode mišljenja, ko je treba veliko različnih konkretnih izkušenj posplošiti, pri čemer se z odmišljanjem nebistvenih podrobnosti poskuša priti do bistvenih značilnosti pojavov in tako ustvariti podlago za splošni pojem. Gre torej za enega izmed postopkov, ki se uporabljajo za oblikovanje splošnih pojmov, kar je bolj domena znanosti, ne toliko stroke. Ker pa je za profesijo predvsem pomembno, da znanje uporablja za reševanje konkretnih nalog in problemov, je ostajanje na abstraktni ravni mišljenja ali zatekanje k njej velikokrat neustrezno. Od izvajalcev profesije se navadno pričakuje ravno obraten postopek: prevedba abstraktnih splošnih pojmov ob stiku z dejanskim stanjem $\mathrm{V}$ konkretno odločitev, z upoštevanjem čim večjega obsega konkretnih, realnih podrobnosti situacije. Ostajanje na abstraktni ravni splošnih pojmov je zato za vojaško profesijo v okviru prakticiranja profesije nesprejemljivo in jo približuje akademski razpravi. Posledica je neučinkovitost v realnosti. Vzrokov za vedno bolj abstraktno mišljenje med vojaškimi profesionalci je lahko veliko: neustrezno izobraževanje, ki ne razvija sposobnosti ustvarjalnega mišljenja, reševanja problemov in sprejemanja odločitev; pomanjkljivo pojmovno in metodično znanje, zaradi česar subsumpcije konkretnega dejanskega stanja posamične situacije pod splošni pojem sploh ni mogoče izvesti; nesposobnost prepoznavanja konkretnih značilnosti posamezne dejanske situacije; pomanjkanje izkušenj, z nizanjem katerih se izostri občutek za prepoznavanje bistvenih značilnosti v posamezni situaciji; nepripravljenost za prevzemanje odgovornosti, ki je vezana na odločanje, saj vsaka konkretizacija s seboj prinaša odločitev, katere druge konkretne možnosti je treba opustiti. Nevarnost, ki jo s seboj prinaša vedno večje abstrahiranje pri prakticiranju vojaške profesije je $\mathrm{v}$ tem, da ustvarja neučinkovite ali celo neizvedljive rešitve, ob čemer se po eni strani prikrito računa na iznajdljivost končnih izvajalcev, na drugi pa na to, da te rešitve ne bodo nikoli uporabljene $\mathrm{v}$ realnosti ${ }^{9}$. Ker se vojaška profesija v povsem realni in skrajni situaciji svoje namembnosti preskusi sorazmerno redko, se lahko takšne neučinkovite rešitve kopičijo, ne da bi bilo to povezano s kakšnimi takojšnjimi večjimi negativnimi posledicami. Vojaški strokovnjaki na vseh ravneh, ki so proizvajalci in uporabniki neučinkovitih rešitev, se na neučinkovitost in odvečnost navadijo ob zavedanju, da morajo iz formalnih razlogov, kot je na primer zadostitev zastarelim predpisom, take rešitve obstajati vsaj na papirju, čeprav v realnosti ne bi bile učinkovite $^{10}$. Vojaški profesionalci, ki so prisiljeni ali pa prostovoljno sprejmejo tak način dela, se prelevijo v uradnike. To pa se je v slovenski vojaški profesiji v veliki meri že zgodilo (oziroma se častniški zbor SV nikoli ni dvignil na raven vojaške profesije).

\footnotetext{
Samo z zelo temeljitim odmišljanjem ali neprepoznavanjem podrobnosti je mogoče ob izdelavi formacij oblikovati enote, ki niti z lastno strukturo niti s konceptualno umestitvijo v širšo strukturo SV nimajo zagotovljenih vseh bojnih funkcij; pripraviti načrte delovanja $v$ različnih razmerah, ki ne rešujejo problema neobstoječe podpore poveljevanja in kontrole; pripraviti načrte delovanja, ki ne upoštevajo taktično-tehničnih lastnosti uporabljenih sredstev ter načel njihove uporabe; $v$ uporabo uvesti sredstva, ki znotraj taktične enote (bataljona) niso povezljiva z drugimi sredstvi; oblikovati in uvesti zmogljivost ter pri tem ne zagotoviti pogojev za namestitev moštva, hrambo materialnih sredstev ter usposabljanje ipd.

${ }^{10}$ Na primer načrt mobilizacije z moštvom in materialnimi sredstvi nepopolnjenih enot, brez rešitve osrednjega vprašanja takšne mobilizacije: kje dobiti manjkajoče moštvo in sredstva.
} 
Vse navedeno kaže na nesistematičen razvoj slovenske vojaške stroke, ki poteka večinoma od spodaj navzgor in se zanaša predvsem na tako imenovano kritično maso $^{11}$ : mit o tem, da je mogoče v hierarhično strukturirani kompleksni organizaciji, kot je SV, brez doslednega vztrajanja pri uveljavljanju doktrine z najvišje ravni, zgolj s povečevanjem števila »prepričanih« na nižjih ravneh, usmeriti razvoj v pravo smer, celo v kakršno koli enotno smer. Pri tem formalni mehanizem, namenjen usmerjanju razvoja prek produkcije doktrine in konceptov na ravni SV, ne le, da nima potrebne pobude pri strokovnem razvoju, temveč s svojo (ne)dejavnostjo niti ne dohiteva tempa razvoja v tistem delu vojaške stroke, ki je v prevzemanje vedno novih rešitev prisiljen zaradi svojega delovanja v mednarodnem okolju.

\subsection{Osnovno izobraževanje in usposabljanje častnikov v Slovenski vojski}

Naslednja značilnost profesije je ustrezen sistem izobraževanja in usposabljanja, katerega standarde določa profesija sama. Izobraževanje in usposabljanje mora ustvariti temelje za pridobitev visoke stopnje specializiranega teoretičnega znanja s področja vojaške stroke ter metod za uporabo tega strokovnega znanja v praksi. Pričakovati je torej mogoče razmeroma dolgotrajno izobraževanje, ki ustvari zadostno količino faktografskega strokovnega znanja in uvid v notranjo povezanost tega znanja ter usmeri mišljenje skladno $z$ načeli stroke. Takšno začetno izobraževanje vojaških profesionalcev v SV traja eno leto, od česar se en mesec izvede kot delovna praksa v enoti ${ }^{12}$. Ker za vstop v Šolo za častnike ni predpisana kakšna določena predhodna izobrazba ali obvezno opravljanje vojaškega modula $\mathrm{V}$ okviru visokošolskega izobraževanja, temveč zadostuje zgolj formalna visokošolska izobrazba katere koli smeri, mora učni program Šole za častnike izhajati iz popolne vojaško-teoretične nevednosti kandidatov. Ob tem se ne more zanašati niti na skupno izhodišče v splošnem znanju. Iz tega sledi, da se povprečen častnik, nosilec vojaške profesije v SV, za samostojno opravljanje profesije izoblikuje v samo enem letu izobraževanja, od česar pa mora biti, zaradi omejenega časa in pretežno veščinske naravnanosti začetnih častniških dolžnosti, velik del časa namenjen veščinskemu usposabljanju (glej Žabkar in Svete, 2008). Vprašanje pa je, ali tako omejen čas osnovnega izobraževanja zadostuje za pridobitev potrebnega teoretičnega znanja in metod za začetno opravljanje vojaške profesije. Vsekakor pa tako kratko strokovno usmerjeno izobraževanje ni primerljivo z drugimi profesijami.

Izobraževanje častnikov se v okviru trajnega izobraževanja vojaških profesionalcev nadaljuje še na štabnem šolanju, višjem štabnem šolanju ter za najvišje položaje v častniški karieri na generalštabnem šolanju, čemur pa se v okviru tega sestavka ne bomo posebej posvečali.

\footnotetext{
${ }^{11}$ Kritična masa je besedna zveza, ki naj bi ponazorila način uvajanja sodobnejših načel v vojaško profesijo prek vedno večjega števila ustrezno naravnanih nižjih častnikov, ki bodo sčasoma, po zasedbi višjih dolžnosti, sodobnejša načela prenesli na celotno vojsko. Kako, kdaj in pod kakšnimi pogoji naj bi se prehod skozi kritično maso na sistemsko raven urejanja zgodil, besedna zveza kritična masa ne opredeli.

${ }_{12}$ Glej Učni progam Šole za častnike SV (GŠSV, št. 603-31/2008-80, 2008).
} 


\subsection{Profesionalna avtonomija in avtoriteta v Slovenski vojski}

Za profesijo sta značilni profesionalna avtonomija in avtoriteta. Prvo je mogoče razumeti kot neodvisnost pri opravljanju profesije, ki temelji na strokovnem znanju in izkušnjah. Vojaški profesionalec je pri prakticiranju profesije samostojen, če se pri svojih odločitvah opira zgolj na vojaško strokovno znanje in izkušnje ter ob tem deluje skladno s profesionalno etiko. Avtonomija je podlaga tudi za profesionalno avtoriteto, torej ugled in vpliv vojaške profesije, ki ji ga na področju njenega udejstvovanja priznava okolje. Kolikor hitro se pojavi dvom v strokovnost znotraj profesije, sta tako njena avtonomija kot avtoriteta postavljeni pod vprašaj. Kdor nima potrebnega znanja, ga ne zna, ne zmore ali ne upa uporabiti, se pri sprejemanju odločitev na svojem področju dela ne more opreti nanj, temveč se mora opreti na nekaj drugega, kar je zunaj njega. To pa pomeni, da je heteronomen. In kdor svojih odločitev ne more razložiti, izhajajoč iz svojega strokovnega znanja, kot profesionalec proti laikom nima avtoritete, čeprav jo morda ima kot človek zaradi drugih lastnosti. Ob prej izraženem dvomu, da je strokovnost v SV na nezadostni ravni in da slovenski vojaški profesionalci svojih odločitev v veliki meri ne zmorejo utemeljiti na znanju in izkušnjah, torej sledi ugotovitev, da slovenska vojaška profesija v povprečju ne more avtonomno odločati in delovati, s tem pa tudi ne more pričakovati, da jo bo okolje na področju vojaške dejavnosti dolgoročno dojemalo kot izključno profesionalno avtoriteto.

\subsection{Profesionalna kultura v Slovenski vojski}

Profesionalna kultura je pojem, ki vsebuje vse značilnosti profesije, jih povezuje $\mathrm{v}$ celoto in tako daje neki profesiji prepoznavnost. Profesionalna kultura kot pojav izraža mero vsake izmed značilnosti znotraj celote. Iz nje je mogoče med drugim razpoznati, katere značilnosti profesije so $\mathrm{v}$ resnici bolj poudarjene in stopajo $\mathrm{v}$ ospredje, včasih tudi na račun ali namesto drugih. Bistven element profesionalne kulture je profesiji lasten kodeks profesionalnega ravnanja, ki povzema in kot obvezujoče za vse člane profesije določa temeljne standarde in običaje profesionalnega ravnanja. SV ima kodeks vojaške etike, ki je enoten za vse pripadnike SV in ni vezan na specifične skupine znotraj SV. Tega kodeksa si vojaška profesija ne določa sama, saj je z Zakonom o službi v Slovenski vojski (ZSSloV, 2007, 4. člen) določeno, da kodeks sprejme Vlada RS. Na ravni SV torej vojaška profesija temeljnih standardov svojega ravnanja ne določa sama. Seveda lahko SV pri oblikovanju teh standardov sodeluje in tudi je sodelovala, kar pa ni nujno. Tako je mogoče reči, da SV ima standarde profesionalnega ravnanja, vendar si jih vojaška profesija ne določa sama, zaradi česar je ena izmed značilnosti profesije vprašljiva. Takšna rešitev je zgolj eden izmed izrazov bolj temeljne umestitve vojaških oseb med javne uslužbence, kar predvsem vojaške profesionalce postavlja v protisloven položaj. Status javnega uslužbenca in običajno dojemanje dolžnosti vojaške osebe sta v nekaterih ključnih lastnostih nezdružljiva. Vojaški profesionalci, poveljniki enot, ki so odgovorni za izvedbo nalog skladno s profesionalnimi standardi, so pogosto postavljeni v položaj, ko morajo te standarde prilagajati oziroma od njih odstopati, da bi spoštovali pravice podrejenih vojaških oseb, ki izhajajo iz njihovega statusa javnih uslužbencev. To 
vojaške profesionalce velikokrat postavi v brezizhoden položaj, ko so odgovorni za profesionalno (pravilno, učinkovito in varno) opravljanje nalog, po drugi strani pa tega ne morejo narediti skladno s profesionalnimi standardi, in sicer zaradi ureditve statusa vojaških oseb, ki ni prilagojena značilnostim vojaške službe. Najpogosteje se v tem položaju znajdejo poveljniki na nižji taktični ravni, ko morajo skladno z načrtom nadrejenega poveljstva zagotoviti pripravljenost enote, pri čemer pa na primer zaradi varstva delavcev v času starševstva $\mathrm{v}$ zvezi z nočnim in nadurnim delom (ZDR, 2002, 190. člen) ne morejo v celoti izvesti potrebnih usposabljanj. Rešitev je navadno ta, da se, če je treba, prilagodijo zahtevani standardi v prepričanju in upanju, da takšne enote ne bo treba uporabiti v realnem bojnem delovanju. Torej rešitev, ki je že bila omenjena v poglavju o strokovnosti. Permisivnost ureditve statusa vojaških oseb sega tako daleč, da v poklicni SV ni mogoče govoriti niti o neomejeni službi. Vojaška oseba lahko v miru, enako kot vsi javni uslužbenci, kadar koli samovoljno neha opravljati svojo službo, ne da bi to imelo kakršne koli kazensko-pravne posledice (izjema je le stanje, ko je pod posebnimi pogoji s pisnim ukazom načelnika Generalštaba SV uvedena povišana pripravljenosti (ZSSloV, 3. člen v povezavi s KZ-1, 273. člen)). Ob taki ureditvi ni vprašljiva le profesionalnost $\mathrm{SV}$ in s tem vojaška profesija, temveč celo sama narava takšne vojaške organizacije, ki služenja ne dojema kot obveznost, temveč kot samovolji posameznikov prepuščeno vsakodnevno odločitev. Prostovoljnost vstopa v vojaško službo pri tem ne igra nobene vloge, saj bi se morala prostovoljnost z vstopom v vojsko v okviru pogojev služenja (za določen čas in pod določenimi pogoji) izčrpati ${ }^{13}$. Tako pa tudi takšna ureditev neizčrpne prostovoljnosti kaže na dojemanje poklicne vojaške službe kot katere koli druge službe v RS. Profesionalna kultura v SV se je sedanjim razmeram ureditve statusa vojaških oseb prilagodila, zaradi česar se ob načrtovanju in izvedbi nalog, celo ob odločanju o povišanju pripravljenosti, zelo veliko pozornosti posveča delovnopravnim zadevam, povezanim s statusom javnih uslužbencev, in iz tega izhajajočim finančnim obveznostim ${ }^{14}$. Profesionalna kultura v SV se tako vedno bolj približuje in izenačuje $\mathrm{z}$ dojemanjem službe in normami ravnanja, kot veljajo na splošno za javne uslužbence.

\subsection{Korporativnost in delovanje znotraj institucionalnega okvira v Slovenski vojski}

Vojaška profesija si v okviru SV še ni ustvarila pogojev, ki bi ji kot profesiji omogočali, da bi razvijala korporativnost, torej združevanje na podlagi skupnega posebnega interesa vojaških profesionalcev. Razvoj korporativnosti zavira več dejavnikov: za vojaško profesijo neustrezna profesionalna kultura kot najširši okvir, neenotno izobraževanje in odsotnost formalnega združevanja vojaških profesionalcev. Za profesijo neustrezna kultura je že sama zadosten razlog za odsotnost

\footnotetext{
${ }^{13}$ Prenehanje prostovoljnosti za pogodbeno določen čas poznajo ZDA in Velika Britanija, ki imajo prav tako poklicno vojsko. Samovoljen (enostranski) izstop iz vojske je v teh državah kazniv.

${ }_{14}$ Tehtanje finančnih posledic povišanja pripravljenosti se najprej pokaže pri odrejanju pripravljenosti na določenem kraju, saj to pomeni 20-odstotno nadomestilo za vsako uro pripravljenosti. Ker normativno ni predpisana obveznost pripadnikov SV, da se ne glede na (ne)odrejeno pripravljenost po potrebi takoj, torej $v$ najkrajšem mogočem času, javijo na delovnem mestu (razen v primeru mobilizacije), je razpoložljivost enot brez formalno odrejene pripravljenosti negotova.
} 
korporativnosti, saj vojaški profesionalci $\mathrm{v}$ takem primeru nimajo skupnega posebnega interesa, zaradi katerega bi se združevali. Izobraževanje vojaških profesionalcev je v preteklosti potekalo in še danes poteka na veliko različnih načinov: $\mathrm{v}$ rednih, izrednih in rezervnih šolanjih nekdanje JLA, v rednih in izrednih generacijah šolanj v okviru SV, v ameriških, angleških in nemških šolah ter v manjšem obsegu drugje v tujini. Skupna izkušnja vojaškega izobraževanja, ki je ob posredovanju znanja tudi temelj za oblikovanje profesionalne kulture, torej med vojaškimi profesionalci v SV ni združujoč dejavnik. V zadnjem času se uveljavlja načelo, da se del častnikov po opravljenem osnovnem izobraževanju častnikov v nadaljevanju kariere izobražuje skoraj izključno v tujih, predvsem ameriških vojaških šolah, s čimer se ohranja in obnavlja prepad, ki ovira oblikovanje skupnih interesov vojaških profesionalcev ter s tem tudi skupne profesionalne kulture ${ }^{15}$.

Slovenski vojaški profesionalci prav tako nimajo formalnega okvira svojega združevanja. Zveza slovenskih častnikov (ZSČ), ki bi se splošno lahko dojemala kot tak formalni okvir, namreč ne združuje vojaških profesionalcev, temveč bistveno širši krog ljudi z različnimi vojaškimi znanji in izkušnjami. »Člani združenj slovenskih častnikov so podčastnice, častnice, podčastniki in častniki, pripadniki stalne sestave Slovenske vojske, njene vojne oziroma rezervne sestave in tisti podčastniki in častniki, ki so brez vojaške razporeditve.« (Spletna stran ZSČ, 2011). Glede na uvodno razmišljanje v prvem poglavju, da je mogoče glede na značilnosti vojaške profesije kot vojaške profesionalce dojemati predvsem častnike, je razvidno, da ZSČ ne združuje zgolj vojaških profesionalcev, torej poklicnih častnikov, temveč tudi podčastnike in rezervne častnike, ki niso nikoli prakticirali vojaške profesije. Z razširitvijo članstva na neprofesionalne strukture se interes takega združenja razširi in ne zastopa zgolj ali pa sploh ne pretežno interesa vojaških profesionalcev. Dejanskemu članstvu ustrezna je tudi dejavnost združenja, s tem pa je združenje nezanimivo za mlajšo profesionalno strukturo SV, ki v njem ne prepozna svojih interesov. Vojaški profesionalci pa drugega formalnega združenja nimajo, torej se formalno ne združujejo za uveljavljanje svojega profesionalnega korporativnega interesa.

Ne glede na ugotovitev o omejeni korporativnosti pa je mogoče ob soočanju vojaške profesije z okoljem zaznati vsaj en skupen in zelo jasen korporativni interes, in to je obstoj vojske v sedanji obliki. Ob soočanju z izzivom zmanjševanja virov in spraševanjem dela javnosti o smiselnosti obstoja SV v trenutni obliki se je ta interes izoblikoval in se začel jasneje izražati. Posledično je na zmogljivosti vojaška profesija začela še bolj poudarjeno gledati skozi njihovo uporabnost v bližnjih nalogah, torej v operacijah kriznega odzivanja v okviru zavezništva, doma pa v podpornem delovanju, predvsem zaščiti, reševanju in pomoči ob naravnih in drugih nesrečah, da bi tako upravičila vložene vire. Vse zmogljivosti morajo tako na neki način poiskati svojo kratkoročno »tržno nišo《 v mirnodobnem delovanju v tujini ali doma, da bi dolgoročno upravičile svoj obstoj in vlaganje vanje. Nevarnost takega načina gledanja na

\footnotetext{
${ }^{15}$ Leta 2011 bo skladno s kadrovskim načrtom na izobraževanje v tujino tako na ravni višjega štabnega šolanja kot na ravni štabnega šolanja napotenih približno 19 odstotkov vseh pripadnikov sil SV. Podatki so pridobljeni iz Kadrovskega načrta sil SV za leto 2011 (PSSV, št. 100-8/2011-10, 2011).
} 
vojaške zmogljivosti je dolgoročno v tem, da se vojaška profesija z vlaganjem zgolj v kratkoročno uporabne, »tržno « zanimive zmogljivosti začne oddaljevati od institucionalnega okvira, ki ji določa njene bistvene naloge, in se znajde v položaju, ko za izvajanje teh bistvenih nalog nima več primernih in zadostnih zmogljivosti, s tem pa dolgoročno tudi ne ustreznega znanja in izkušenj.

\section{ALI JE VOJAŠKA PROFESIJA SPLOH MOGOČA?}

V prvem poglavju so navedene značilnosti vojaške profesije. Nanizane so iz različnih virov, pri čemer se na tistem mestu vprašanje o združljivosti posameznih značilnosti ni izpostavilo. Večina navedenih bistvenih značilnosti vojaške profesije izhaja iz splošnega pojma profesije, ki je podlaga za vsakršno pojmovanje profesije, dodana pa je posebna značilnost delovanja $v$ institucionalnem okviru. Poleg tega so posamezne značilnosti vsebinsko dopolnjene glede na specifično področje dejavnosti in temu ustrezne organiziranosti vojaške profesije. Vprašanje pa je, koliko ta vsebinska posebnost in institucionalna umestitev vojaške profesije še ustrezata splošnemu pojmu profesije. Kot morebitne problematične se kažejo značilnosti profesionalne avtonomije ter hkratno navajanje korporativnosti in delovanja znotraj institucionalnega okvira.

Ena izmed bistvenih značilnosti profesije je profesionalna avtonomija. Profesionalno avtonomijo je sicer mogoče razumeti kot avtonomijo profesije, torej kot samostojnost pri odločanju v lastnih zadevah na ravni profesije, kot samostojnost profesije kot celote v odnosu do laikov, drugih poklicev, profesij ali institucij. Toda opredelitev profesionalne avtonomije samo na ravni profesije kot celote je nezadostna, saj ostaja splošna in abstraktna. V realnosti ne obstaja in deluje profesija, profesije ne prakticira splošni pojem, temveč posamični profesionalci. Avtonomijo profesije je zato treba razumeti tudi, mogoče celo predvsem, kot avtonomijo profesionalcev, da samostojno, skladno s svojim strokovnim znanjem in običaji profesije, ter seveda v okviru danega pravnega reda sprejemajo odločitve na področju svojega dela, za katere potem tudi odgovarjajo. Brez avtonomnih profesionalcev je težko govoriti o avtonomiji profesije. Na tem mestu pa se postavi vprašanje, kako je tovrstna avtonomija profesionalcev mogoča $v$ hierarhično organizirani strukturi, kot je vojska. Ali je pojem vojaška profesija, vsaj ko gre za profesionalno avtonomijo, pravzaprav oksimoron? Vsi pripadniki vojske so zavezani subordinaciji pri opravljanju svojih nalog. Načelo subordinacije je za vojsko tako temeljno, da se splošno dojema kot del njene kulture. K subordinaciji vse pripadnike SV zavezuje zakon (ZObr-UPB1, 2004, 43. člen). V okviru odločitve nadrejenega so sicer lahko avtonomni, toda ta avtonomnost je $\mathrm{v}$ večini primerov omejena na iskanje najustreznejšega načina izvedbe odločitve nadrejenega, ne glede na to, koliko je odločitev strokovno utemeljena. Skladno z omejeno avtonomijo pa je omejena tudi odgovornost za dejanja v okviru odločitve nadrejenega. Pripadniki vojske tako ne le, da niso poklicani k strokovni presoji odločitev nadrejenih, v okviru katerih morajo delovati, temveč taka presoja, torej kritika, tudi ni zaželena in dovoljena. Čeprav bi bila po njihovi oceni odločitev nadrejenega strokovno sporna, morajo delovati v okviru in skladno s tako odločitvijo. 
Tako hierarhično razmerje velja v celotni strukturi vojske in ne ločuje med profesionalci in drugimi. Tako je tudi častniški zbor kot nosilec vojaške profesije zavezan istemu načelu subordinacije. Res je sicer, da ko gre za razvoj strokovnega znanja, raziskovanje in strokovno razpravo o posameznih vsebinah, torej za razvoj profesije kot celote, subordinacija nima velike vloge, saj gre za načelo, ki ureja predvsem izvajanje službe. Toda za profesijo je bistven prav ta, izvedbeni del, v katerem se uresničuje. In v tem delu je avtonomija vojaških profesionalcev bistveno okrnjena zaradi najpomembnejšega načela hierarhične strukture vojske - subordinacije. Tudi če je torej vojaška profesija navzven avtonomna, njeni člani v njenem izvrševanju večinoma niso. Koliko je torej sploh mogoče govoriti o vojaški profesiji, če je profesionalna avtonomija, ena bistvenih značilnosti profesije, sistemsko okrnjena? Ali pa je treba to profesionalno avtonomijo razumeti zgolj kot že omenjeno avtonomijo vojaške profesije kot celote nasproti drugim dejavnostim, ne glede na heteronomnost njenih članov? Ali je mogoče profesionalno avtonomijo razumeti tako, da se člani profesije $\mathrm{z}$ vstopom $\mathrm{v}$ vojaško profesijo in sprejetjem njenih specifičnih standardov ravnanja sami zavestno in prostovoljno omejijo na ozko sfero delovanja znotraj meja odločitve nadrejenega, iz svoje strokovne presoje zavestno izključijo strokovno utemeljenost odločitve ter temu rečejo specifična vojaška profesionalna kultura? V tem primeru med seboj trčita dve značilnosti profesije, avtonomija in profesionalna kultura, ki v okviru običajnega in povprečnega razumevanja pojmov avtonomije in subordinacije ne moreta obstajati hkrati.

Dve značilnosti, ki si na prvi pogled ne nasprotujeta, morda trčita tudi, ko govorimo o delovanju znotraj institucionalnega okvira in korporativnosti. Vsaka zase sta ti značilnosti vojaške profesije morda smiselni. Njuno vzporedno navajanje pa zahteva nekaj premisleka o naravi institucionalnega okvira in korporativnosti. Vojaška profesija se realizira $v$ okviru državne vojske, ali pa to ni vojaška profesija - to je poenostavljen pomen institucionalnega okvira v obdobju nacionalne države (glej Žabkar, 2008). Vse državne institucije in organi delujejo zgolj skladno z občim (nacionalnim) interesom, ki ga $\mathrm{v}$ običajnih razmerah uteleša država skozi zakonite odločitve njenega vodstva. Vsakršno mešanje posebnih ali celo posamičnih interesov v delovanje državnih organov te oddalji od temeljnega namena njihovega obstoja. Institucionalni okvir delovanja vojaške profesije torej pomeni, da ta deluje izključno v občem interesu, ali pa je pod vprašajem njena profesionalnost. Po drugi strani korporativnost pomeni zasledovanje posebnega interesa korporacije kot združenja mnogih posameznikov z nekim skupnim, vendar ne občim interesom. Če je torej značilnost vojaške profesije tudi korporativnost, se postavi vprašanje, kakšen poseben interes združuje in usmerja korporacijo vojaških profesionalcev in ali je ta posebni interes skladen z občim oziroma mu je podrejen. Samo po sebi to ni nujno in lahko se zgodi, da začne vojaška profesija zasledovati korporativni interes, ki preglasi ali celo nasprotuje njenemu občemu institucionalnemu poslanstvu. Ob oblikovanju in zagovarjanju svojega posebnega interesa se lahko opre na drugo korporacijo vojaških profesionalcev, pri čemer je lahko ta nadnacionalna ali pa izoblikovana $\mathrm{v}$ okviru drugega nacionalnega institucionalnega okvira. Posledica obojega je lahko, da korporativni interes vojaških profesionalcev preseže nacionalni institucionalni interesni 
okvir, tudi kadar z njim ni v neposrednem nasprotju ${ }^{16}$. Iz tega sledi, da sta korporativnost in institucionalni okvir potencialno izključujoči značilnosti, kar navaja na ugotovitev, da je treba določiti, katera izmed teh značilnosti je po prioriteti višja in tako postavlja omejitve pri izražanju druge ali jo morda celo izključuje. Če je prioriteten institucionalni okvir delovanja vojaške profesije, morajo biti s tem institucionalnim okvirom omejene možnosti korporativnosti. Če pa je prioritetna korporativnost in ji torej niso postavljene nikakršne omejitve, potem je nemogoče zagotoviti delovanje v okviru institucionalnega okvira.

Glede na vlogo vojske in v njenem okviru vojaške profesije sta torej vsaj dve značilnosti, ki naj bi bili bistveni za profesijo, vprašljivi. To sta profesionalna avtonomija in korporativnost. Ti značilnosti, ki sta konstitutivni za splošnejši pojem profesije (ne zgolj vojaške), sta tisti, ki postavljata vojaško profesijo nad institucionalni okvir, v katerem naj bi delovala. Vsaj za avtonomijo je bilo že nakazano, da je na ravni avtonomije posamičnih vojaških profesionalcev vprašljiva, vprašljiva pa je tudi na ravni vojaške profesije kot celote. Ta je namreč v okviru razumevanja vojske kot sredstva politike ter njene podreditve civilni oblasti vezana tudi na in omejena s politiko, ki jo oblikujejo in izvajajo pristojni civilni državni organi, in ne zgolj z načeli in običaji lastne stroke. Kar lahko takšno vezanost in omejenost preseže, je zgolj korporativnost, ki posebne interese vojaške profesije postavi in uveljavi nad občim interesom, zaradi katerega sploh obstaja. Tako vojaška profesija dejansko postane profesija v polnem pomenu besede in vse, kar vojaškim profesionalcem preprečuje ustanavljanje in delo v zasebnih vojaških (varnostnih) podjetjih, je morebitna restriktivna zakonodaja, ki vsakršno vojaško dejavnost veže v institucionalni okvir.

Sklep Vprašanje, ali je SV profesionalna oziroma ali je trenutna pot profesionalizacije prava, je odvisno od tega, kako je definirana vojaška profesija. V sestavku sta prikazana eden izmed mogočih načinov razumevanja vojaške profesije in eno izmed videnj trenutnega stanja vojaške profesije v SV. Glede na uvodno postavljen namen razprave je mogoče reči, da slovenska vojaška praksa v svojih bistvenih značilnostih trenutno ne ustreza splošnemu pojmu profesije, torej ni mogoče govoriti o slovenski vojaški profesiji. Še posebno se to nanaša na prvo značilnost vsake profesije, strokovno znanje ${ }^{17}$. Profesionalnost tako za zdaj ostaja cilj, ki si ga SV vsaj na deklarativni in formalni ravni prizadeva doseči.

Toda vprašanje o možnosti vojaške profesije, postavljeno proti koncu, odpira dilemo o izvornem vprašanju samem. Ali je vpraševanje o profesionalnosti sploh bistveno vprašanje? Bolj kot oznaka profesionalnosti so pomembne jasna vizija in odločitev o

\footnotetext{
${ }^{16}$ Posledice prevlade korporativnega (pa tudi posamičnega) interesa se lahko kažejo pri neustreznih nabavah opreme, prevzemanju določenih tujih konceptov, zagovarjanju tujih interesov ali celo kot neposredno vplivanje tujih korporacij (vojaških ali drugih) na institucionalne odločitve. Primer zadnjega je neprikrito vplivanje oblasti ZDA prek povezav vojaških korporacij na dogajanje v Egiptu februarja 2011 (Bumiller, 2011).

${ }_{17}$ Ugotovitev o podkvalificiranosti slovenskih častnikov povzema tudi Jelušič v razpravi Kaj lahko obramboslovje prispeva k povečanju profesionalnosti častnikov in častnic Slovenske vojske. Razprava je bila objavljena v Biltenu Slovenske vojske.
} 
tem, katere in kakšne značilnosti v SV želimo, ter temu ustrezna sistemska ureditev službe v SV, in sicer ne glede na to, ali temu rečemo profesionalna vojska ali kako drugače. Splošni pojmi, ki niso zadostno konkretizirani, namreč velikokrat bolj zastrejo kot razjasnijo pogled na pojave, ki naj bi jih definirali. In profesionalnost je lahko takšen pojem.

Ustreznejše kot splošno govorjenje o profesionalnosti in profesionalizaciji je torej povsem konkretno vpraševanje in odločanje o tem, kako zagotoviti ustrezen okvir ter pogoje za razvoj Slovenske vojske kot sodobne vojaške organizacije s specifičnimi nalogami, specifičnimi pogoji dela in iz tega izhajajočimi specifičnimi zahtevami. Nedoslednost pri zagotavljanju pogojev dela in delovanja ob vedno večjih zahtevah in pričakovanjih povzroča frustracijo predvsem med tistimi pripadniki Slovenske vojske, ki naj bi bili nosilci vojaške profesije. Odločiti se za vojsko in ne zahtevati neomejene službe, je sprenevedanje. Odločiti se za vojsko in ji ne zagotoviti osnovnih pogojev za delovanje in realistično usposabljanje, je sprenevedanje. Odločiti se za profesionalno vojsko in popuščati pri temeljnih standardih vojaške stroke, je sprenevedanje. V miru se takšno sprenevedanje lahko prikrije z uprizarjanjem v detajle insceniranih prikaznih vaj, izdajanjem izvrstnih promocijskih izdelkov in dobrimi odnosi z javnostmi. V realni situaciji pa se vsako sprenevedanje povrne kot neučinkovitost in neuspešnost, ki je v bojnih razmerah večinoma povezana z izgubami. Pravo vprašanje torej ni, ali imamo oziroma želimo profesionalno vojsko. Pravo vprašanje je, ali bomo na podlagi lastnega uvida zmogli s teoretičnim mišljenjem oblikovati takšne okvirne pogoje ter metode dela in usposabljanja Slovenske vojske, ki bodo z razpoložljivimi viri omogočali uresničevanje njenega poslanstva $\mathrm{v}$ realnih pogojih bojnega delovanja, ne da bi najprej potrebovali lastno travmatično izkušnjo neuspeha. Prav to pa je bistvena lastnost vojaške profesije.

1. Bumiller,E., 28. januar 2011. Egyptian Military Chiefs Cut Pentagon Visit Short. Spletna stran New York Times, (http://www.nytimes.com/2011/01/29/world/ middleeast/29militaryegypt.html? scp $=6 \& s q=$ egypt + military + pentagon $\& s t=n y t)$.

2. Bumiller, E., 29. januar 2011. Calling for Restraint, Pentagon Faces Test of Influence With Ally. Spletna stran New York Times, (http://www.nytimes.com/2011/01/30/world/ middleeast/30military. $h t m l$ ? scp $=3 \& s q=$ egypt + military + pentagon\&st $=n y t)$.

3. Bumiller, E., 10. marec 2011. Pentagon Places its Best Bet on a General in Egypt. Spletna stran New York Times, (http://www.nytimes.com/2011/03/11/world/middleeast/11enan. html scp $=1 \& s q=$ egypt $\% 20$ military\%20pentagon\&st=cse).

4. Jelušič, L., 1997. Legitimnost sodobnega vojaštva. Ljubljana, FDV.

5. Jelušič, L., 2008. Kaj lahko obramboslovje prispeva k povečanju profesionalnosti častnikov in častnic Slovenske vojske; v Biltenu Slovenske vojske 2008-10/št.1. Ljubljana, $G \check{S} S V$.

6. Kazenski zakonik. Uradni list RS, št. 55/2008.

7. Resolucija o splošnem dolgoročnem programu razvoja in opremljanja Slovenske vojske do leta 2025. Uradni list RS, št. 99/2010.

8. Sarkesian, S. C.; Connor, R. E. Jr., 2006. The US Military Profession into the Twenty-first Century. New York, Rutledge. 
9. Zakon o obrambi-UPB1. Uradni list RS, št. 103/2004.

10. Zakon o vojaški dolžnosti - UPB1. Uradni list RS, št. 108/2002.

11. Zakon o službi v Slovenski vojski. Uradni list RS, št. 68/2007.

12. Zakon o delovnih razmerjih. Uradni list RS, št. 42/2002.

13. Zveza slovenskih častnikov, 2011. Predstavitev organizacije ZSČ. (http://www.zsc.si/index. php? page $=$ static\&item $=1$ ).

14. Žabkar, A., 2008. Ahilovi peti sistema izobraževanja častnikov; v Biltenu Slovenske vojske 2008-10/št.1. Ljubljana, GŠSV.

15. Žabkar, A., in Svete, U., 2008. Šolanje vojaških profesionalcev med tradicionalnimi izhodišči in (post)modernimi izzivi; v Biltenu Slovenske vojske 2008-10/št.1. Ljubljana, $G \check{S} S V$. 